\title{
The Lebanese Students' Awareness on the Concept of Corporate Social Responsibility
}

\begin{abstract}
By Aline Al Am*
Corporate Social Responsibility (CSR) is a broad topic that covers a multitude of concepts and ideas. It has become a global phenomenon that makes use of innovative approaches for solving social, environmental and economic problems with the aim to increase the benefits for society, in general, and for the stakeholders of organizations, in particular. CSR has existed as a concept for over 70 years. Although CSR is mainly promoted by large companies, mainly multinational enterprises, it is also important for other types of organizations such as universities. Its wider application towards universities is of central importance, since universities are the greatest contributors for the formation of forthcoming entrepreneurs, business leaders, managers and employees. (Wright T, 2010). In Lebanon, there is a consistent need for the community to live in a safe, clean and healthy environment. Despite many efforts on behalf of sustainability and social responsibility in Lebanon, most social and environmental trends have not been effective. Therefore, universities should be presently open to promote a sustainable growth strategy. The implementation of CSR initiatives in the universities will contribute towards awareness raising and dissemination of the concept. This research's main aim is to investigate the level of CSR awareness in the Lebanese society then to identify the role of universities in promoting CSR among the future generations. (JEL M14, Q01, $\mathrm{I} 23, \mathrm{O} 53)$
\end{abstract}

Keywords: Corporate Social Responsibility, Universities, Lebanon, Sustainable Development, Students.

\section{Introduction}

Everywhere, companies are struggling to fulfill a new role, which is to meet the needs of the present generation without compromising the ability of the next generations to meet their own needs. Organizations are being called upon to take responsibility for the ways their operations influence societies and the natural environment. Globalization has increased the awareness of businesses regarding their responsibility toward the development of society and CSR is widely accepted as an appropriate commitment to ensure sustainable benefit for both corporations and communities.

As organizations do not operate in vacuum, their activities will impact their environments which include their stakeholders, society, and other influenced parties. We can argue that the responsibility of addressing global issues ideally involves everyone, since everyone is in some way impacted. Everyone should strive for a sustainable tomorrow. Unquestionably, all humans have moral obligations to preserve the planet and there is no excuse for not doing something to improve the environmental state of the globe.

*Assistant Professor, Department of Management, Faculty of Economics and Business Administration, Lebanese University, Branch III, Lebanon. 
This also applies to institutions of higher education. Universities, as the centers of knowledge generation and sharing, play a very important role in solving world's problems by creating a sustainable future. Education could play a key role in helping communities to adopt principles of sustainable development. They play a major role in spreading CSR principles in the mind of students in order to build a responsible society, aware about the importance of sustainability. Universities are the best contributors for the formation of future entrepreneurs, business leaders, managers and employees. Environmentally responsible citizens accept responsibility for what happens in their community-not only environmentally but also politically and socio economically.

Sustainability issues and CSR should be integrated within the main program and activities of university education and research processes, different operational activities of the university and its community as well as the relations of the university with the external community. Every institution of higher education, including students, teachers, researchers, administration and other staff, has to follow sustainable development principles.

However the question is to discover:

To what extent the universities are playing a role in promoting CSR and what is the level of CSR awareness in the Lebanese Society?

To answer this, the study seeks to look more in depth onto the social roles and responsibilities of the Lebanese universities by studying the integration of CSR in the teaching programs and activities of the universities and this can be achieved by studying and exploring the role played by those universities in creating CSR awareness in the Lebanese society.

\section{Corporate Social Responsibility: Concept, Evolution and Practices}

Corporate social responsibility (CSR) is the intentional application of sustainable development by the companies which means that they incorporate in their activities the three pillars of sustainable development: economy, society and the environment by taking into account the expectations of stakeholders. Corporate Social Responsibility is an emerging field which has gathered bigger attention recently, business and academic researchers have shown increasing levels of interest in CSR during recent years.

\section{An Overview of CSR}

CSR is about businesses and other organizations going beyond the legal obligations to manage ethically the impact they have on the environment and society. In particular, this could include how organizations interact with their employees, suppliers, customers, and the communities in which they operate, as well as the extent to which they attempt to protect the environment. While the development of a society depends on the businesses that succeed in its environment, the success of a business also depends on the stability of that society. The well-being of one depends directly on the well-being of the other. Thus, 
corporations need to understand and redefine their roles in order to fulfill their social responsibilities. They need to look beyond government-initiated development programs and take charge of directing initiatives aimed towards improving the health and standard of living of their community. Businesses that integrate social responsibility into their missions acknowledge that their business processes have an impact beyond the company.

Table 1. Definitions of CSR (own elaboration)

\begin{tabular}{|c|c|c|}
\hline Author & Year & Definition \\
\hline Bowen & 1953 & $\begin{array}{l}\text { CSR refers to the obligation for entrepreneurs to } \\
\text { implement strategies, to take decisions and to } \\
\text { guarantee practices that are compatible with the } \\
\text { objectives and values of the community in } \\
\text { general. (Bowen, 1953) }\end{array}$ \\
\hline Davis & 1960 & $\begin{array}{l}\text { CSR is the set of decisions taken for reasons that } \\
\text { exceed the economic or technical interest of the } \\
\text { firm. (Davis, 1960) }\end{array}$ \\
\hline McGuire & 1963 & $\begin{array}{l}\text { CSR assumes that the company does not only } \\
\text { have legal or economic obligations, but also has } \\
\text { responsibilities to society that go beyond those } \\
\text { obligations. (McGuire, 1963) }\end{array}$ \\
\hline Friedman & 1970 & $\begin{array}{l}\text { CSR is to use its resources and engage in activities } \\
\text { designed to increase its profits. (Friedman, 1970) }\end{array}$ \\
\hline Carroll & 1979 & $\begin{array}{l}\text { CSR encompasses all the economic, legal, ethical, } \\
\text { and discretionary expectations that society } \\
\text { expects from its organizations. (Carroll, 1979) }\end{array}$ \\
\hline Wartick and Cochran & 1985 & $\begin{array}{l}\text { CSR is the underlying intersection between the } \\
\text { principles of social responsibility, the process of } \\
\text { social sensitivity and the policies implemented to } \\
\text { deal with social problems. (Watrick, S. and } \\
\text { Cochran, P., 1985) }\end{array}$ \\
\hline Wood & 1991 & $\begin{array}{l}\text { CSR is the intersection of three principles: } \\
\text { legitimacy, public responsibility and managerial } \\
\text { discretion. These result from three levels of } \\
\text { analysis, institutional, organizational and } \\
\text { individual. (Wood, 1991) }\end{array}$ \\
\hline Clarkson & 1995 & $\begin{array}{l}\text { CSR is the ability to manage and satisfy the } \\
\text { various stakeholders of the company. (Clarkson, } \\
\text { 1995) }\end{array}$ \\
\hline $\begin{array}{l}\text { World business } \\
\text { council for sustainable } \\
\text { development }\end{array}$ & 2000 & $\begin{array}{l}\text { CSR is the commitment of business to behave } \\
\text { ethically and to contribute to economic } \\
\text { development while improving the quality of life } \\
\text { of the workforce and their families as well as the } \\
\text { local community and society at large. (WBCSD, } \\
\text { 2000) }\end{array}$ \\
\hline $\begin{array}{l}\text { Commission of the } \\
\text { European } \\
\text { Communities }\end{array}$ & 2001 & $\begin{array}{l}\text { A concept whereby companies decide voluntarily } \\
\text { to contribute to a better society and a cleaner } \\
\text { environment. (CEC, 2001) }\end{array}$ \\
\hline Kakabadse & 2005 & $\begin{array}{l}\text { The basic idea of corporate social responsibility is } \\
\text { that business and society are interwoven rather } \\
\text { than distinct entities. (Kakabadse, 2005) }\end{array}$ \\
\hline
\end{tabular}


CSR means different things to different people, there are varied views on what CSR is and what it is not. Although it had become a slogan, CSR is more often misunderstood as giving back to the society and considered to be identical to philanthropy. The dominant school of thought is that CSR is no philanthropic activity and a business must earn for what it invests. Corporate Social Responsibility is confused with corporate philanthropy or charity, but it is a very different thing. Corporate philanthropy has a more restricted scope than CSR; it refers primarily to donations made to charitable and non-profit groups, whether by the corporation, its employees or both. CSR not only deals with corporate philanthropy but also with further concerns that affect the environment, consumers, human rights, supply-chain sustainability and transparency for the greater good of the world at large. It should address how to be a good citizen in the community; CSR is about the organization's obligations to all stakeholders and not just shareholders. Organizations must manage and plan relationships with their stakeholders. The stakeholders are the ones with vested interests in the organization, and those who can influence its way of doing business and thus future opportunities to succeed.

There are a large number of definitions for CSR. However, the recurrent theme of these definitions regards an organization's defined responsibilities to its communities and its environment. These are some of the most important definitions of CSR.

\section{The Pyramid of Corporate Social Responsibility}

Viewing CSR from Carroll's pyramid, we can say that the concept presents four dimensions: economic, legal, ethical and philanthropic; and this can be illustrated in a pyramid as presented in figure 1. Carroll contends that all of these responsibilities have always existed to some degree, but ethical and philanthropic responsibilities have become significant only in recent years.

- Economic Responsibilities: "Be profitable, Maximize sales \& Minimize costs."

Economic responsibilities relate to business's provision of goods and services in society. . Profits result from this activity and are necessary for any other responsibilities to be carried out. It is assumed that corporations will be as profitable as possible, maintain a strong competitive position and maintain a high level of operating efficiency. It is well known that many developing countries suffer from a shortage of foreign direct investment, as well as from high unemployment level and widespread poverty. It is no surprise, therefore, that the economic contribution of companies in developing countries is highly prized, by governments and communities alike. Fox (2004) argues that this should not be seen in negative light, but rather as a more development-oriented approach to CSR that focuses on the enabling environment for responsible business in developing countries and that brings economic and equity aspects of sustainable development to the forefront of the agenda. 
- Legal Responsibilities: "Obey laws and Regulations."

The society expects businesses to conform to laws and regulations. Corporations are expected to pursue profits within the framework of the law, which establishes what are considered as fair operations. The society expects that all goods and services and relationships with stakeholders should meet at least minimal legal requirements. This does not necessarily mean that companies flaunt the law, but there is far less pressure for good conduct. This is because; in many developing countries the legal infrastructure is poorly developed and often lacks independence, resources and administrative efficiency.

- Ethical Responsibilities: "Do what is right, fair and just."

This includes those activities that are not expected or prohibited by society as economic or legal responsibilities. Standards, norms or expectations that reflect concern for selected stakeholders input is fair, just, or in keeping with their moral rights. Ethics or values may be reflected in laws or regulations, but ethical responsibilities are seen as embracing the emerging values and norms that society expects of business even if not currently required by law. These responsibilities are more difficult for businesses to deal with as they are often ill-defined or under continual public debate. Ethical responsibilities are also found in the fundamental ethical principles of moral philosophy, such as justice, human rights and utilitarianism, the changing or emerging ethical responsibilities are constantly pushing legal responsibilities to broaden mere compliance with laws and regulations.

\section{- $\quad$ Philanthropic Responsibilities}

It involves being a good corporate citizen and including active participation in acts or programs to promote human welfare or goodwill. Examples are contributions to the arts, charities and education. Such responsibilities are not expected in an ethical or moral sense, making philanthropy more discretionary or voluntary on the part of business even though society may have such expectations of business. Few in society expect corporations to have these responsibilities and they can be thought of as things corporations "might do". Companies realize that they cannot succeed in societies that fail, and philanthropy is seen as the most direct way to improve the prospects of the communities in which their businesses operate.

In summary Carroll's views the total social responsibility of business as involving the simultaneous fulfillment of the four responsibilities which are stated in pragmatic terms, meaning that the corporation should strive to make a profit, obey the law, be ethical and be a good corporate citizen. 
Figure 1. The Pyramid of Corporate Social Responsibility (Carroll, 1991)

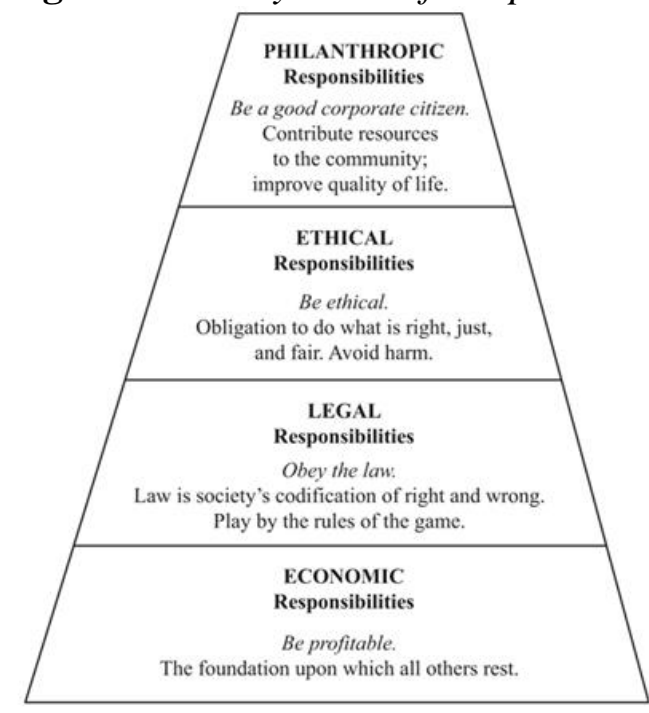

History and Evolution of the CSR Concept

The arrival of CSR in academic literature has a long history. CSR was first mentioned in monographs in 1926 by Clark (Clark, 1926) who notes that a business has obligations to society. Other early monographs include Barnard (Barnard, 1938) and Kreps (Kreps, 1940) who look to the inclusion of social responsibilities within the obligations of business. With Howard Bowen, CSR becomes the object of significant academic interest as he published the famous book "Social Responsibilities of the Businessman" in 1953 and he is considered to be the founding father of CSR.

The 1960s saw CSR as continuing to struggle for definition. Different authors provided specific reflections. A large evolution has been recorded. Despite this evolution, many continued to focus on the economic returns to shareholders, recognizing that CSR could advance the self-image of the corporation. Drucker in 1984 proposes a new meaning for CSR giving a role to the Third Sector and focusing on the possibility to transform social responsibilities in business opportunities (Drucker, 1984). The 90's were also very rich in this concern especially in extending the concept to complementary ones such as corporate social performance, ethics in business and corporate social responsiveness. In the last decades the CSR concept has been enriched in different theories of the firm: stakeholder theory, institutional theory and resource based view.

All the definitions of CSR provided throughout the years can be divided into two different categories. Phillip Kotler and Nancy Lee (Kotler, P. and Nancy, L., 2005) refer to these two categories as the "traditional approach" and the "new approach". This division is established on the main idea that companies' view of CSR has developed from being seen as fulfilling an obligation to be seen as a strategic tool.

The traditional approach mainly covers definitions prior to the 1990s when CSR was seen as an obligation. Basically, this approach was followed for a long time, till recently, and the companies following this approach apply CSR only 
because it would raise their recognition in the market. They did not practice these activities because of the interest in the well-being of the society. The only reason behind it was to form their corporate image. Commitments were short term, allowing the organization to spread the wealth over a variety of organizations and issues throughout the years. Companies taking this approach simply engage in CSR to look good, and allocate money to many organizations, believing that this creates the most visible effort. The initiatives are not supporting the company's strategic business goals but reflecting the wishes and preferences of the management of the company often resulting in a short-term commitment.

The new approach arose in the 1990s when the conception of CSR changed from being seen as obligatory to be viewed as a strategic tool that can support a company's activities and by this mean positively affect a company's image and reputation. . It supports corporate objectives as well. This is a win-win situation for all because when a particular company does well to the society honestly and for a cause, it has to be good, and along with this process, it succeeds in building a good name. This shift is also evident in the CSR definitions that take point of departure in this approach. (Kotler, P. and Nancy, L., 2005)

Since entering into the twenty-first century, more focus has been given to implementation of CSR initiatives and empirical study of CSR impacts.

The following table shows some areas of focus a business can look at for its CSR projects and strategies:

Table 2. Internal \& External CSR strategies (Own elaboration)

\begin{tabular}{|c|c|c|c|}
\hline \multicolumn{2}{|c|}{ Fields } & \multirow[b]{2}{*}{\begin{tabular}{l}
\multicolumn{1}{c}{ Activities } \\
Reduce consumption of \\
energy, water \& other \\
natural resources \\
Use or produce recycled \\
and recyclable materials \\
Use 'green' power \\
electricity suppliers \\
Join or start a 'green \\
business' club
\end{tabular}} & \multirow[b]{2}{*}{$\begin{array}{r}\text { Results } \\
\text { Reduced pollution }\end{array}$} \\
\hline \multirow{3}{*}{ 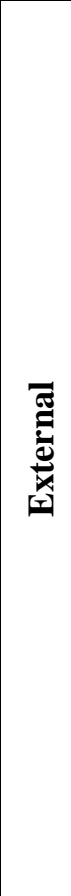 } & Environment & & \\
\hline & Market & $\begin{array}{l}\text { Excellent service delivery } \\
\text { Customers education } \\
\text { Buy from local suppliers } \\
\text { and strive to hire locally }\end{array}$ & $\begin{array}{l}\text { Customers satisfaction } \\
\text { Word of mouth }\end{array}$ \\
\hline & Society & $\begin{array}{l}\text { Support organizations } \\
\text { that promote fair trade } \\
\text { and human rights } \\
\text { compliance } \\
\text { Use some of the } \\
\text { marketing budget to } \\
\text { associate the business or } \\
\text { brand with a social cause }\end{array}$ & $\begin{array}{l}\text { Relationship with local } \\
\text { community } \\
\text { Recognition by stakeholders }\end{array}$ \\
\hline
\end{tabular}




\begin{tabular}{|c|c|c|c|}
\hline \multirow{3}{*}{ 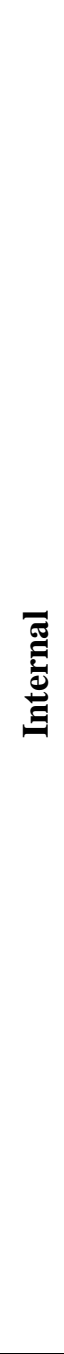 } & Product & $\begin{array}{l}\text { Use organic or natural } \\
\text { ingredients in production } \\
\text { High quality products } \\
\text { Make some products or } \\
\text { services free or at cost to } \\
\text { charities }\end{array}$ & $\begin{array}{l}\text { Business reputation } \\
\text { Publicity }\end{array}$ \\
\hline & Employees & $\begin{array}{l}\text { Be open to job splitting, } \\
\text { flex-time and other work- } \\
\text { life balance policies } \\
\text { Involve employees in } \\
\text { business decisions that } \\
\text { affect them } \\
\text { Fair wages and salaries } \\
\text { Employee wellness } \\
\text { programs } \\
\text { Encourage employee } \\
\text { volunteering }\end{array}$ & $\begin{array}{l}\text { Low staff turnover } \\
\text { Motivated employees } \\
\text { Reduced rate of absenteeism } \\
\text { High staff morale } \\
\text { Increased productivity } \\
\text { Increased company } \\
\text { engagement }\end{array}$ \\
\hline & Organization & $\begin{array}{l}\text { Establish policies to } \\
\text { ensure the health and } \\
\text { safety of all employees } \\
\text { Commit to an external } \\
\text { standard that provides a } \\
\text { framework to measure } \\
\text { progress on } \\
\text { environmental and social } \\
\text { issues } \\
\text { Make sure to have } \\
\text { explicit policies against } \\
\text { termination of any } \\
\text { employee on the basis of } \\
\text { gender, race, religion and } \\
\text { others }\end{array}$ & $\begin{array}{l}\text { New business opportunities } \\
\text { Sustainability }\end{array}$ \\
\hline
\end{tabular}

\section{The Higher Education Sector in Lebanon}

Lebanon's higher education sector is the oldest in the region. It was established in 1866 with the foundation of the American University of Beirut (AUB) followed by the University of Saint Joseph (USJ) in 1875, then by the Lebanese American University (LAU) in 1947 as the Beirut College for Women. The only public university established in the country, the Lebanese University (LU), was founded in 1951. Haigazian University was founded in 1955, followed by the Beirut Arab University (BAU) in 1960 operating in collaboration with the Egyptian university of Alexandria. Most of the higher education institutions currently in operation in Lebanon were certified in the late nineties when the private sector prospered in an unexpected and rapid expansion following the 15 year civil war that Lebanon suffered between 1975 and 1990 and which had a very negative impact on the country's higher education sector.

The freedom and independence of Lebanese higher education are protected under the Constitution. The Lebanese University (LU) enjoys clear autonomy with 
its own system of governance. Despite the fact that the Faculties of the Lebanese University have many branches spread all over the country, the responsibility of managing the Faculties is in the hands of the Deans, and the management of the university is in the hands of the University Council. The private sector is governed by the law of 1960. In 2002, a Directorate General for Higher Education (DGHE) was established to regulate the private higher education sector, and supervise and coordinate all actions related to it. The DGHE is in charge of the private higher education institutions currently in operation in the country. Apart from the licensing and the validation of the degrees and disciplines offered by the Institution which must be validated by the DGHE, all other responsibilities are in the hands of each institution's governing body.

Concerning the systems adopted in the higher education sector, the two oldest universities, the American University of Beirut and the "Université Saint Joseph", adopt the American and French systems respectively. The old yearly based French system has been changed in almost all the universities to the European 3-cycle system; Bachelor-Masters-Doctoral (BMD) system. The two major systems in Lebanon are the American and European ones and almost all of the higher education institutions adopt a form of 3-cycles credit-based system. However, some variations exist since some universities adopt the Canadian system, others the German system and the Beirut Arab University adopts the Egyptian-Arab system.

As for the system in general, the credits systems also vary from one institution to another. There is no national credit system that allows the transfer, recognition and mobility of the students. The two major classes of credits' systems are: the American Credit system and the European Credit Transfer and Accumulation system (ECTS). The American credits are roughly based on contact-hours. The ECTS is student-centered and accounts the relative workload of the student in average.

The organization of the research activities are also done by the institutions solely. At the national level, the National Council for Scientific Research offers some financial support to reviewed research projects. It also defines and supports associated research units. At the institutional level, several universities have established structures to encourage and promote the research activities. Moreover, the Lebanese researchers participate to some regional and international projects. It is worth noting that often the professors and active researchers at the Lebanese higher education institutions have maintained their contacts and cooperation with the research units they have visited during their $\mathrm{PhD}$ preparation.

International cooperation is another dimension of the Lebanese higher education. The Lebanese higher education has been and still remains attractive for a significant set of students from the region. Besides, several Lebanese universities have opened branches in the Gulf region. At the international level, the Lebanese universities have well established cooperation with foreign universities abroad. At the educational level, the Lebanese universities in general participate actively in Tempus and Erasmus Mundus projects. At the research level, the Lebanese universities participate in EU (FP6, FP7) projects as well as several USAID projects. CEDRE program has also been supporting research cooperation between 
Lebanon and France. Several other cooperation programs exist. However, there are no clear policies regarding the organization and development of the international dimension in the Lebanese Higher Education.

When it comes to the distribution of students by gender, it can be observed that the proportion of female students exceeds the proportion of males by eight percentage points, with females accounting for $54 \%$ of students and males constituting the remaining $46 \%$. As for the nationality of students in higher education, the majority are Lebanese ( $86 \%$ share), while non-Lebanese account for $14 \%$ of students.

Concerning the distribution by major, we can say that the statistics done during the academic year 2011-2012 are still significant with small variations. Almost $27 \%$ of students were enrolled in Business and Economics majors. Literature and Humanities (Language, Translation, History, Philosophy..) accounted for $14.8 \%$ of total students. Whereas $11.7 \%$ of students majored in Engineering (Architecture, Civil, Mechanical, Electrical, Agricultural, Interior, Landscape...) and 9.1\% of students majored in Natural Sciences (Physics, Chemistry, Biology..) and Mathematics. Law major ranks sixth in popularity with a $5.5 \%$ of total higher education students, followed by Pharmacy, Nursing, and Laboratory (3.9\%), as well as Media, Press, and Advertising (3.5\%). Lastly come Medicine, Education, and Teaching with $2.9 \%$ and $1.9 \%$ of total students, respectively.

\section{Methodology and Findings}

This section presents the research methodology or the design of the research while stating respectively the research objective, the defended thesis, the hypotheses, the epistemological positioning and the followed approach.

The problematic answers the question "what am I looking for?" In this research the research question, referred to in the introduction is:

To what extent the universities are playing a role in promoting CSR and what is the level of CSR awareness in the Lebanese Society?

To answer this question, the study will first focus on the degree of integration of CSR into the universities' teaching programs and activities and finally the goal is to discover whether this integration can affect the behavior of their students in order to measure the level of CSR awareness in the Lebanese society.

Thus, the research question is aimed at finding a positive relationship between two variables - the integration of CSR in Universities and the creation of student awareness about the subject.

The hypotheses to be tested in this research are:

H1: Education provides the basics for people's mind development resulting in accepting the change toward the best behavior.

$\mathrm{H} 2$ : The teaching courses in Universities programs related to CSR and sustainability influence students' behavior toward sustainability in order to create agents of change in society 
H3: The universities engagement into sustainable activities influences students' behavior toward sustainability

This research is situated in the positivist paradigm where reality is given objectively and is independent of the observer. In this case, the research follows a hypothetical-deductive approach illustrated in the figure below:

Figure 2. The Stages of the Hypothetico-deductive Approach (Depelteau, 2010)

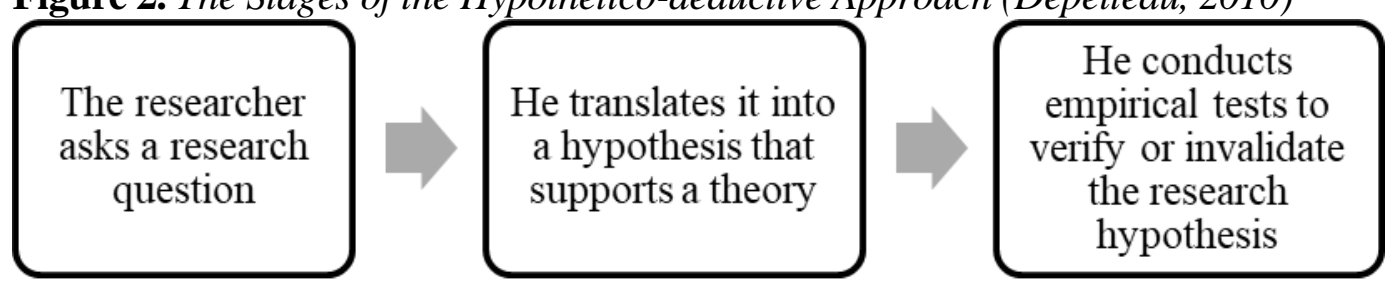

The questionnaire is a tool used to collect information in order to understand and explain realities. By nature, the questions of the questionnaire can be open, closed or mixed. In this research, we adopted only closed questions. As we know, the closed questions can be either dichotomous which means that they come with two modalities of response or polyatomic, that is to say, with several modalities of response. The closed questions present some advantages which increase their use: the collection of the answers is simple, the coding of the information is immediate, the information collected is uniform and in some cases the closed-ended questions provoke reflection. The disadvantages found in such type of questions are related to the fact that the answers do not provide an indication of whether the questions were understood or not and in some cases they do not express the exact answer that the respondent wants to provide.

The method of administering the questionnaire will differ, concerning the presentation of the questions to the interviewees; we can distinguish two types of administration: in the first type the questionnaire is explained by the interviewer and it is distributed face to face or by a telephone call and in the second type the questionnaire is self-administered by making it available to the public using several techniques of which the two most dominant are mailing and posting on the Internet. In this research, we sent the questionnaire by email in order to reach as many persons as possible and to collect the data quickly. This mode of administration doesn't need a budget; it is fast and provides good quality data.

The questionnaire used in this research is divided in two parts; the first one is related to general information needed to discover the population in the study while the second part composed of 16 questions is more specific. The questions of part 2 focus on discovering the importance of CSR provided by the universities, some questions of the questionnaire are related to the practices, activities or the courses associated to CSR implemented by the university, while other questions are oriented toward understanding the role played by university in promoting CSR and to discover how a university can play the role of an agent of change in the society. The answers of most of the questions follow the Likert scale while the question related to the awareness is binary. The collected data is analyzed using "SPSS" software. 
The study has focused on some of the top universities located in Lebanon mainly the Lebanese University, Balamand, USJ, USEK, CNAM and NDU taking into consideration their different branches in order to cover most of the Lebanese regions. The sample is composed of 207 respondents divided into 99 male and 108 female. 90 of the respondents are students of the Lebanese university while 117 are from the different private universities. The answers come from different regions of Lebanon as follows: 18 from Beyrouth, 72 from the North of Lebanon, 54 from the South, 27 from Bekaa and 36 from Mount Lebanon.

We have randomly selected a certain number of students from different specializations at the universities mentioned before. The sample includes 18 students of Business and Economics, 36 students of Literature and Social Sciences, 36 students of Engineering and Architecture, 81 students of Medicine, 18 students of Law and Political Sciences, 9 students of Sciences and 9 students of Arts and Music. The selected students are in different academic years.

The study shows that around $70 \%$ of students are not aware about the importance of CSR while 30\% are aware. The level of awareness is higher in the private universities comparing to the Lebanese University (public). This is due to the different activities organized on the campus of the private universities. Most of the activities covered are related to the protection of the environment.

The AUB and LAU have boosted PRO-GREEN-A Joint/Dual Professional Degree in Green Technologies offering a diploma in green technologies intended for those already working in the fields of engineering and architecture. The program offers opportunities to focus on sustainability in energy, water and buildings. PROGREEN can be completed on the internet, making it the first professional diploma of its kind in the region. The study program comprises 55 courses and 87 credit hours. Environmental concerns are also at the heart of the University of Balamand. Accordingly the university decided to set up an Institute of the Environment (IOE) in order to address ecological worries through both research and activity.

MAJAL, the Academic Urban Observatory, launched in 2008 the project entitled "Promoting Sustainable Construction in Lebanese Universities" dedicated to bringing issues to light on particular sustainable development strategies.

In addition, the "Reorient Curricula to Address Sustainability" (RUCAS) project was launched in October 2010. Its main goal is to help six partners in Lebanon, Jordan and Egypt to set in Environmental Sustainable Development into their curricula and teaching methodology through capacity building of university staff. Among these universities are the NDU and Sagesse University. Many other universities have their own initiatives along with the community. We have just presented a general idea of what is being done by the Lebanese Universities in order to build a better society looking for economic prosperity while keeping planet resources viable for future use.

The research demonstrates that the respondents are looking to CSR as environmental concerns only and missing the social concerns.

After collecting the data via the questionnaire, we used the correlation in order to verify $\mathrm{H} 1$. The correlation is useful when we want to study the relationship between two or more variables. In our case we find opportune to study the 
relationship between the level of education and the engagement in different activities revealing the awareness on CSR in the mind of students like volunteering, being aware of pollution, reducing consumption, using renewable energy, waste sorting, and consuming organic food. A correlation coefficient is a statistical measure of the degree to which changes to the value of one variable predict change to the value of another. In positively correlated variables, the values increase or decrease in tandem. In negatively correlated variables, the value of one variable increases as the value of the other decreases.

Table 3 shows this relationship. We can deduce that the level of education doesn't have any impact on any of the chosen variables (volunteering, awareness of pollution, reducing consumption, use of renewable energy, waste sorting and consumption of organic food). (sig $>0.05$ ). This result can be probably explained by the absence of teaching courses related to CSR given to the students in their academic study.

In this case H1 is rejected; the variable "years of education" by itself doesn't have any impact on CSR practices. For this reason the research is oriented to study the impact of the teaching courses on CSR given by the university on changing the mind of the students.

Table 3. Correlation between Level of Education and the Different Activities

\begin{tabular}{|c|c|c|c|c|c|}
\hline \multicolumn{2}{|c|}{} & $\begin{array}{c}\text { Renewable } \\
\text { Energy }\end{array}$ & $\begin{array}{c}\text { Waste } \\
\text { Sorting }\end{array}$ & $\begin{array}{c}\text { Organic } \\
\text { Food }\end{array}$ & $\begin{array}{c}\text { Level of } \\
\text { Education }\end{array}$ \\
\hline \multirow{3}{*}{$\begin{array}{c}\text { Level of } \\
\text { Education }\end{array}$} & $\begin{array}{c}\text { Pearson } \\
\text { Correlation }\end{array}$ & $-.173^{* *}$ & $.431^{*}$ & $-.102^{* *}$ & $1^{*}$ \\
\cline { 2 - 6 } & Sig. (2-tailed) & .113 & .071 & .142 & \\
\cline { 2 - 6 } & $\mathrm{N}$ & 207 & 207 & 207 & 207 \\
\hline
\end{tabular}

**. Correlation is significant at the 0.01 level (2-tailed)

*. Correlation is significant at the 0.05 level (2-tailed)

Table 4 illustrates the correlation between the number of CSR courses taken by the students and the achieved implementation of different activities. We can deduce that the number of courses related to CSR given by the university to the students has a positive impact respectively on the awareness on pollution, reducing consumption and choosing organic food. Regarding the other variables where there is no impact (sig>0.05) the behavior of the students can be explained in different ways.

We realize that the students of the final years are focusing on searching for their first job and therefore are not interested in volunteering, while for reducing the consumption and using the renewable energy the research shows that the teaching courses are not focusing on these two variables as well as the other areas of CSR.

In this case $\mathrm{H} 2$ is confirmed for the reasons explained above even though not all the variables have positive correlation. The teaching courses play a major role in spreading awareness on CSR. Since we have a considerable deficiency in the awareness of CSR concept and strategies, the programs should cover all areas of CSR. Students must have a better idea of the different CSR strategies and must clearly distinguish between CSR and Sustainability. 
Universities assume a special role in promoting a collective strategy for growth on a sustainable basis, through the development of an adequate educational offer and scientific research, in the scope of corporate social responsibility and sustainable development. There are many ways in which universities can get involved in CSR and sustainable practices like: education, research, management, planning development, purchasing, transportation, construction, renovation, and community service.

Table 4. Correlation between the Number of Courses and the Different Activities

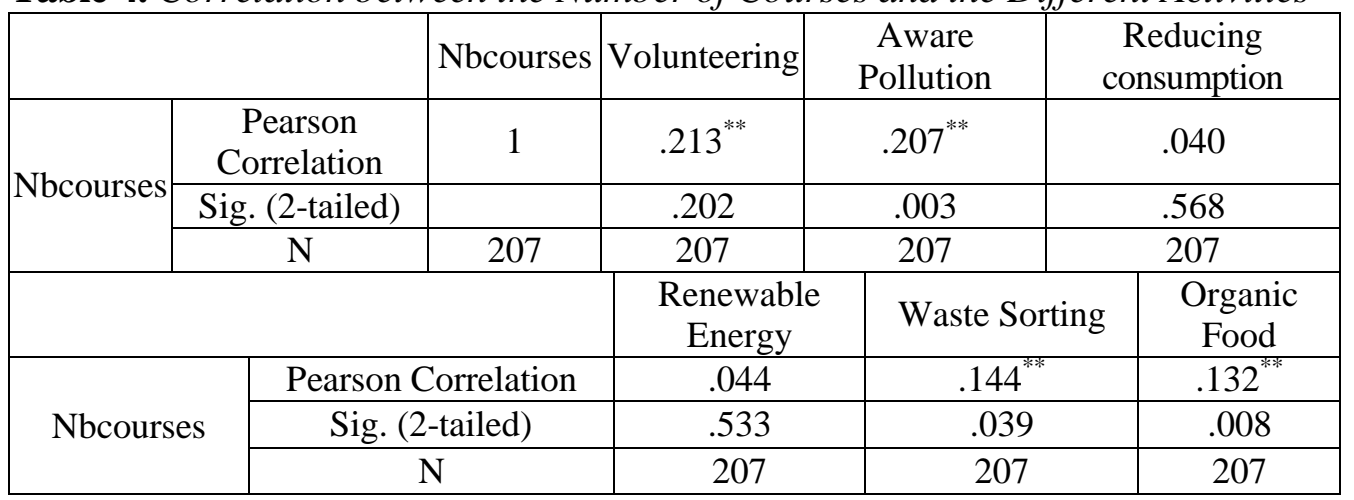

**. Correlation is significant at the 0.01 level (2-tailed)

*. Correlation is significant at the 0.05 level (2-tailed)

In order to verify $\mathrm{H} 3$, we used the logistic regression illustrated in table 5 . It is known that the Logistic regression is a class of regression where the independent variable is used to predict the dependent variable. In our case the independent variables are: the campaigns organized by the university, activities aimed to reduce consumption, the use of renewable energy, the waste sorting and the dependent variable is the awareness of students on CSR leading to change in their behavior toward sustainability.

The results show that the campaigns, the use of renewable energy and the waste sorting have a significant impact on the awareness of students ( $\operatorname{sig}<0.05)$ while reducing the consumption doesn't have any impact. Possibly the university is working on reducing consumption but the students of the studied sample are not aware about the activities achieved by the university in this field. We can conclude that $\mathrm{H} 3$ is partially confirmed since three activities out of four have significant impact.

Table 5. Logistic Regression

\begin{tabular}{|c|c|c|c|c|c|c|}
\hline \multicolumn{7}{|c|}{ Variables in the Equation } \\
\hline & $\mathrm{B}$ & S.E. & Wald & $\mathrm{df}$ & Sig. & $\operatorname{Exp}(B)$ \\
\hline Campaigns & -2.696 & .507 & 28.224 & 1 & .000 & .067 \\
\hline Reducing consumption & -1.051 & .716 & 2.155 & 1 & .142 & .350 \\
\hline $\operatorname{1}_{\mathrm{a}}^{\mathrm{step}}$ Renewable Energy & -2.888 & .531 & 29.604 & 1 & .000 & .056 \\
\hline Waste Sorting & -3.291 & .771 & 18.209 & 1 & .000 & .037 \\
\hline Constant & 5.259 & 1.067 & 24.279 & 1 & .000 & 192.280 \\
\hline
\end{tabular}

Variable(s) entered on step 1: Campaigns, Reducing consumption, Renewable Energy, Waste Sorting 


\section{Conclusion and Recommendations}

In Lebanon, we have a consistent need to implement CSR and sustainable practices in the overall society. The ranking of Lebanon regarding transparency worldwide is embarrassing. The solution may come from the new generation. The main responsibility of institutions of higher education is to prepare their students through increasing the awareness on CSR, knowledge, skills and values needed to create a sustainable future. Universities are key players in promoting new dynamics at institutional and social networks. They have a double role, first, to improve the students' quality of life on a sustainable basis and second to educate with values oriented toward social and human values.

CSR practices should be integrated within the main functions of a university: education and research processes, different operational activities of the university and its community as well as the relations of the university with the external community. All the members of higher education including students, teachers, researchers, administration and other staff, have to implement CSR and sustainable development principles.

The main results of this research can be resumed as follow:

- The more universities integrate CSR practices in their teaching programs the more students are aware about its importance and are driven by sustainable thinking

- The organization of activities by the different universities can have more influence on students' behavior

- The level of education may have a positive impact if complemented by teaching courses and activities related to CSR

Every research has its own limits. In this case the random selection of the sample and the number of the respondents might have not been optimally representative. The study was oriented to the environmental concerns of CSR without taking into consideration the social concerns like: human rights, labor practices, organizational governance...

In order to better address the issue of CSR awareness among university students, the following suggestions are to be taken into consideration by the different universities:

- Enrich the programs in the different faculties by teaching courses on the CSR concept and practices

- Suggest ways in which the institution might go "beyond the campus" into the community

- Undertake more initiatives as the students would do the same when they see that their universities are committed to the mission and not implementing CSR to show-off

- Encourage students participation and empower them to give ideas through brainstorming and decision making 
Universities in developing countries like Lebanon should consider the world leading universities as their benchmark not only in academic areas as they are doing but also in issues of social responsibility and sustainability.

Future research must be oriented to assess how the promotion and implementation of CSR at Universities will reinforce the credibility of such organizations and basically to cover the other areas of CSR missing in this study. It is also fundamental to help to introduce sustainable development principles in all areas of universities activities in order to assure reasonable use of resources, education content and process based on sustainable development.

\section{Bibliography}

Barnard, C. (1938). The Functions of the Executive. Cambridge, MA: Harvard University Press.

Bowen, H. (1953). Social Responsibility of the Businessman. New York: Harper \& Row.

Carroll, A. (1979). Three-Dimensional Conceptual Model of Corporate Performance. Academy of Management Review, 4, 497-505.

Carroll, A. (1991). The pyramid of corporate social responsibility: Toward the moral management of organizational stakeholders. Business Horizons, 34(4), 39-48.

CEC. (2001). Green Paper.Promoting a European Framework for Corporate Social Responsibility. Comission of the European Communitites, Brussels, Belgium.

Clark, J. (1926). Social Control of Business. Chicago, IL: University of Chicago Press.

Clarkson, M. (1995). A stakeholder framework for analysing and evaluating Corporate Social Perfromance. Academy of Management Review, 20(1), 92-117.

Davis, K. (1960). Can Business afford to ignore social responsibilities? California Management Review, 2, 70-76.

Depelteau, F. (2010). The approach of a social sciences and humanities research:From the initial question to the communication of the results. De Boeck Université.

Drucker, P. (1984). The new meaning of corporate social responsibility. California Management Review, 26, 53-63.

Friedman, M. (1970). The social responsibility of business is to increase its profits. The New York Times Magazine, sept13.

Kakabadse, N. (2005). Corporate social responsibility and stakeholder approach:A conceptual review. International Journal of Business Governance and Ethics, January.

Kotler, P. and Nancy, L. (2005). Corporate Social Responsibility-Doing the Most Good for Your Company and Your Cause. USA: John Wiley \&Sons INC.

Kreps, T. (1940). Measurement of the Social Performance of Business. In K. Wright, An Investigation of Concentration of Economic Power for the Temporary National Economic Committee. Washington, DC: US Government Printing Office.

McGuire, J. (1963). Business and Society. New York: McGraw-Hill.

Watrick, S. and Cochran, P. (1985). The Evolution of the Corporate Social Performance Model. Academy of Management Review, Oct 1,758-769.

WBCSD. (2000). Corporate Social Responsibility: Making Good Business Sense. Geneva: Word Business Council for Sustainable Development.

Wood, D. (1991). Corporate social performance revisited. Academy of Management Review, 16, 691-718. 
Wright, T. (2010). University presidents'conceptualizations of sustainability in higher education. International Journal of Sustainability in Higher Education, 11(1), 61-73.

\section{Websites}

Directorate General for Higher Education, http://www.higher-edu.gov.lb/

Center for Educational Research and Development, Lebanon http://www.crdp.org

National Tempus Office - Lebanon http://www.tempus-lebanon.org/ 
